\title{
North American Indian Language
}

National Cancer Institute

\section{Source}

National Cancer Institute. North American Indian Language. NCI Thesaurus. Code C158073.

Any of the languages indigenous to Alaska, Nunavut, Greenland, the United States, and the northern areas of Mexico. 